\title{
From state agencies to ordinary citizens: reframing risk-mitigation investments and their impact to disrupt urban risk traps in Lima, Peru
}

\author{
ADRIANA ALLEN, LINDA ZILBERT SOTO AND JULIA WESELY, IN COLLABORATION \\ WITH TERESA BELKOW, VLADIMIR FERRO, RITA LAMBERT, IAN LANGDOWN AND \\ AMARU SAMANAMÚ
}

\begin{abstract}
The understanding of linkages between disaster risk and urban development has seen important advances in recent decades. However, it falls short in addressing the production and reproduction of so-called urban "risk traps", which are accumulation cycles of everyday risks and small-scale disasters with highly localized impacts, particularly on impoverished urban dwellers. Drawing on the action-research project cLIMA sin Riesgo, this paper examines risk-mitigating investment actions of state agencies, residents and communities in Barrios Altos, in the historic centre of Lima, Peru, and José Carlos Mariátegui, in the periphery. The analysis shows that residents tend to be caught in risk traps not necessarily due to lacking investments, but paradoxically despite them and their unintended effects. Furthermore, accumulated fragmented investments erode the capacity to act of those at risk and perpetuate risk accumulation cycles. The paper argues for a re-assessment of riskmitigation investments and their intended and unintended consequences, and suggests routes to address current shortcomings in order to disrupt "risk traps".
\end{abstract}

KEYWORDS capacity to act / everyday risk / just and resilient cities / Lima / risk-mitigation investments / urban risk traps

\section{INTRODUCTION}

The understanding of conditions of risk in urban contexts has significantly changed in the last two decades, the period in which debates on disaster risk management (DRM) have shifted from a focus on the evaluation of hazards and impacts of disaster events ${ }^{(1)}$ to analyses of vulnerabilities and capacities to act, ${ }^{(2)}$ to today's discourse on urban risk and resilient cities. ${ }^{(3)}$ This latter discourse has strengthened the recognition that risks and their management are intrinsically connected to socially constructed processes . Addressing this relationship calls for close examination of the links between disasters and development, and of the historical bias towards large-scale events at the expense of the slow violence of everyday risk accumulation that increases the vulnerabilities of low-income dwellers to environmental hazards. ${ }^{(4)}$

As argued in the 2016 World Disasters Report, ${ }^{(5)}$ building resilience means "saving lives today and investing for tomorrow". However, this requires a re-assessment of what disaster risk reduction and prevention involves when confronting not just large-scale events but the accumulation of extensive risk that underpins urbanization across the global South.

The concept of "extensive risk" - used to describe the risk associated with low-severity, highfrequency events, often associated with highly localized hazards - provides an analytical entry point to this debate. In recent years, extensive risks have received increasing attention in national and international policymaking circles due to the growing evidence of their accumulated impacts in terms of damage and asset losses, which can supersede those of large-scale events when examined over a time period of about 10 years. ${ }^{(6)}$ Yet extensive risks remain largely invisible to policymakers, a problem aggravated by current methodological and data shortcomings, which fail to account for the bulk of their impacts. ${ }^{(7)}$ Furthermore, the prevailing framing of everyday and small-scale risks as cumulative threats to assets and goods suggests that their incipient recognition in policy circles is primarily driven by economic and financial concerns. This motivates this paper to re-problematize the way risk-mitigation investments undertaken across different scales work and their actual impact on tackling risk accumulation cycles.

Debates on financing disaster risk management have long focused on decision-making based on the economic costs and benefits of investing to prevent and reduce the estimated damage of largescale disasters. The consideration of urban everyday risks has been largely absent from such debates. 
A meta-review on disaster risk management investment analyses by Mechler extends this discussion to small-scale events and argues that

"in general, for the low-to-medium loss risk layers aggregating events that happen relatively frequently, prevention is likely more economically efficient in reducing burdens than insurance. The reason is that the costs of prevention often increase disproportionately with the severity of the consequences. Moreover, individuals and governments are generally better able to finance lower-consequence events from their own means, for instance, savings or calamity reserve funds, and including international assistance."(8)

Mechler further argues that cost-benefit analysis is insufficient to move beyond infrastructure-based options towards preparedness actions. Hence he calls for research on other tools such as multi-criteria analyses to support robust decision-making processes and more systemic interventions.

Building on these premises, this article draws on the findings from a two-year action-research project entitled cLIMA sin Riesgo, ${ }^{(9)}$ which since 2015 has worked in two marginalized and contrasting areas of Metropolitan Lima: ${ }^{(10)}$ José Carlos Mariátegui in the periphery, and Barrios Altos in the historic centre. The project involved an in-depth participatory analysis of who is most affected by small-scale and everyday risks, how, where and why; and also a critical assessment of local dwellers' and state agencies' capacity to act to confront risk accumulation cycles. Examining the latter through the risk-mitigating investments made over time in both areas from multiple sources, the analysis is underpinned by two main considerations.

First, the paper analyses government investments in disaster risk reduction and urban development at the national, metropolitan, municipal and district levels. It demonstrates that policies and programmes by the state that aim to improve the quality of life of inhabitants in Lima largely fail to translate into risk-reducing investments in the most vulnerable settlements. Critically, some investments were found to unintentionally counteract disaster risk reduction efforts by increasing risks for residents or transferring them elsewhere. Hence, looking at allocated budgets and implemented investments across sectors helps to capture their unintended impact in deepening and displacing risk accumulation, both socially and geographically.

Second, the consequences of these unintentionally risk-increasing investments are analysed in relation to the specific spatial and temporal dynamics that help to explain how risk accumulation cycles or urban "risk traps" are produced and reproduced over time and where. We use the concept of "risk traps" to capture how particularly marginalized low-income urban dwellers find themselves in situations of increased exposure and vulnerability to environmental hazards, paradoxically despite and even because of investments undertaken to improve their precarious living conditions.

"Risk traps" are here defined as the sum of the articulation and reproduction of vulnerability and daily and episodic dangers or threats, coupled with eroded capacity to act. ${ }^{(11)}$ The use of the concept is based on the premise that risk traps are frequently invisible or neglected in the management and planning of cities, and that their reproduction is caused to a large extent by a flawed and misleading appraisal of what constitutes and causes risk in the first place. Creating conditions that are necessary to move out of risk traps requires engaging with different actors' capacity to act - of which investment capacities form one part - in the realms of social inclusion policies, urban development and environmental sustainability.

The analyses of over 700 georeferenced surveys conducted at the household and block/settlement levels, as well as a desktop review of relevant policies and programmes at the national, metropolitan, municipal and district levels, suggest that current investments in decreasing risk need to be re-assessed in order to capture their intended and unintended impacts. More often than not, efforts to avert risk consider how much is invested in managing disasters, but do not account for the investments made in responding to the longer-term risks created by inadequate provision in public services, infrastructure, housing and land tenure security. The paper suggests routes to address current shortcomings in order to ensure that ongoing investment flows effectively disrupt "risk traps". 


\section{BACKGROUND}

\section{a. Lima and its cumulative risk challenges}

Peru is a country with a high incidence of large-scale disaster events, such as tsunamis, earthquakes and droughts. ${ }^{(12)}$ Climate scenarios suggest that the El Niño-Southern Oscillation (ENSO) cycle exacerbates the incidence of landslides, mudslides, floods, intermittent and sudden periods of heavy rainfall, and droughts, which has implications for both large- and small-scale disaster risk management. Between 2006 and 2010, national annual economic losses due to climate-related disasters - both larger- and smaller-scale events - amounted to about US\$ 73 million, and 22,000 emergencies affected 6 million people. ${ }^{(13)}$ Over 30 per cent of Peru's population live in Metropolitan Lima; importantly, the distribution of disaster risks is neither geographically nor socially even. ${ }^{(14)}$ Records from the DesInventar database, which captures the occurrence of small-scale disasters, indicate that 19 per cent of all events recorded in Metropolitan Lima between 1970 and 2011 occurred in the district Cercado de Lima, where the case study area Barrios Altos is located and which hosts an estimated 270,000 out of 9.7 million inhabitants in Lima ${ }^{(15)}$ (Figure 1). Fires, pollution, structural collapse of buildings, floods and landslides are registered as the major hazards that lead to smallerscale events. ${ }^{(16)}$ However, this largely underestimates the high incidence of multiple small-scale disasters in the poorest and most populated districts in the periphery of the metropolis, which are rarely registered and thus remain invisible at the scale of the city as a whole.

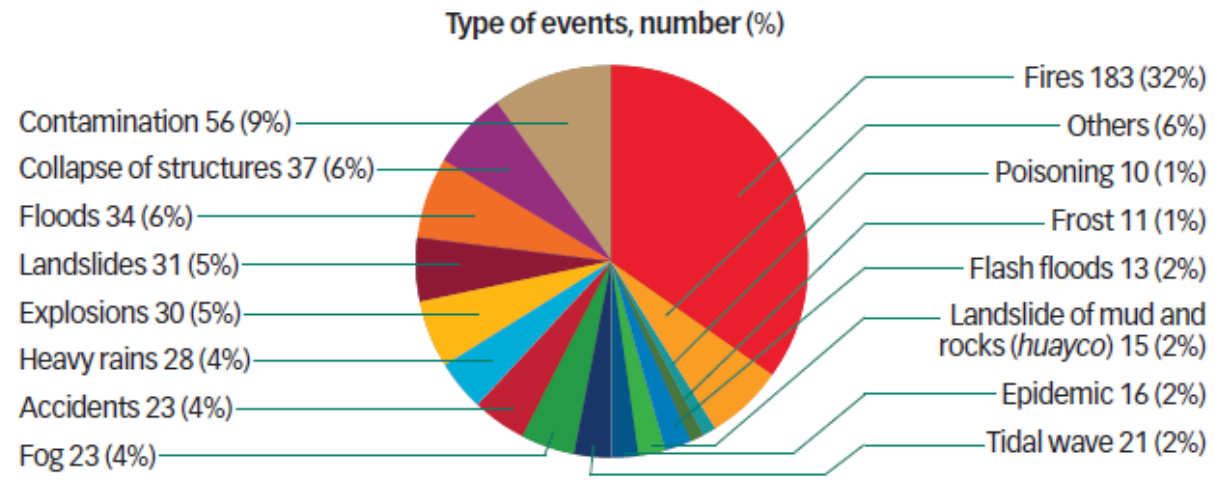

The DesInventar Database illustrates the incidence of episodic small-scale disasters in Metropolitan Lima from 1970 to 2011 , demonstrating that the disasters related to fires, pollution, structural collapse, floods and landslides are the most common and occur with most frequency in the central District Cercado de Lima, an area that concentrates $19 \%$ of the cases. Nevertheless, the majority of extensive disasters happen on the periphery of Lima but are rarely registered, remaining invisible on the scale of the city as a whole.

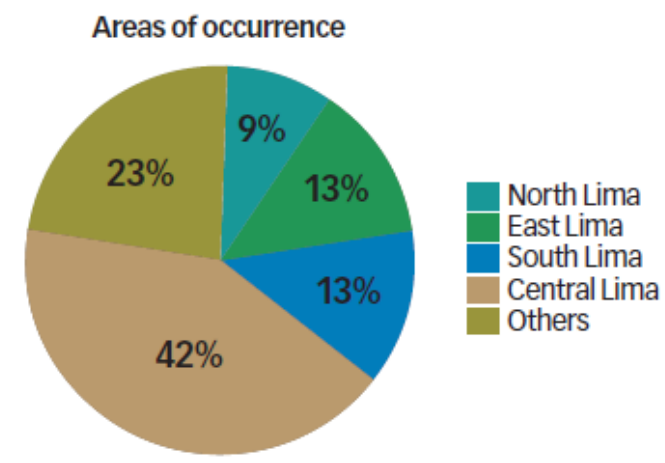

Figure 1 Types of small-scale disaster events and areas of occurrence in Metropolitan Lima between 1970 and 2011

SOURCE: LA RED (2013), DesInventar: Inventory system of the effects of disasters, Version 10.01.007, accessed 4 August 2016 at https://online.desinventar.org/desinventar/\#PER-1250695241-peru_inventario_historico_de_desastres.

NOTES:

Contamination $=$ "Concentration of contaminating substances in the air, water or soil, at levels which are damaging to human, animal, or plant life".

Poisoning = "Poisoning by gas or food". 
Peruvian Law 29,664 of 2011 forms the basis for the current National System of Disaster Risk Management (SINAGERD) - officially described as an "inter-institutionalized, synergized, decentralized, transversal and participatory system" - which has the objective of identifying and reducing risks and minimizing their effects, to avoid the creation of new risks and to ensure preparedness and attention in the event of disasters. The Presidential Council of Ministers (PCM) governs this system, and coordination and implementation of national policies are the responsibility of the Secretary for Disaster Risk Management. Key supporting agencies are the National Centre for Assessment, Prevention and Disaster Risk Reduction (CENEPRED) for technical support, the National Institute of Civil Defence (INDECI), and - for financial support - the Ministry of Finance and Economy (MEF). Regional and local governments have the responsibility for incorporating disaster risk management into their strategic development plans.

While the design of SINAGERD has been lauded for being advanced, particularly for largescale disaster management, ${ }^{(17)}$ its actual implementation has been challenged by a lack of prospective strategic actions. Another difficulty has been its insufficient consideration of the complexity and interaction of risks at different temporal and spatial scales with diverse frequencies and types of impacts. ${ }^{(18)}$

Due to its demographic and economic significance, Metropolitan Lima has been the focus of national efforts in improving current disaster risk management and preventing and mitigating future damage and economic losses. Lima is the second most populated desert metropolis in the world, after Cairo Its central position in the national economy, together with a nation-wide armed conflict between Shining Path (a Maoist guerrilla group) and security forces in the 1980s and 1990s, attracted many migrants, leading to a tenfold increase in population to almost 10 million inhabitants currently, half of whom live on the sprawling steep slopes of the periphery in the poorest districts of Lima East and Lima North. ${ }^{(19)}$ Although the population growth rate has decreased in the last decade, the 2011 Census shows that Metropolitan Lima has the highest rate of extreme poverty and the largest increase in overcrowded housing in the country. ${ }^{(20)}$

In order to understand how small-scale and everyday risk management links to different actors' capacities to invest, it is crucial to emphasize how social inequalities within Lima interact with environmental and ecological challenges such as water scarcity and steep topography. The rivers of Metropolitan Lima bring rainwater from the Andes to the city, but they are seasonal and heavily used for industrial purposes; commercial and residential water demands are met through large-scale infrastructural projects to reduce contamination and sedimentation and transfer water from the Atlantic to the Pacific basin. ${ }^{(21)}$

Despite these efforts - according to the National Statistical Institute (INEI) in 2011 - almost 1.5 million inhabitants of Metropolitan Lima were unable to cover the high costs of their basic needs for potable water and sanitation. ${ }^{22}$ Although 74 per cent of dwellings are reported to have water connections, vast differences can be found on the ground in terms of access to adequate services. Some households have as little as 50 litres/day from the water network, while higher income areas use 460 litres/day. Those, which are not connected to the network, consume less than 25 litres/day, while paying about 10 times more per litre than those with water connections. ${ }^{(23)}$ Insecure water access and unsafe water quality are closely related to diseases such as diarrhoea, affecting children and the elderly disproportionately in the barriadas or low-income settlements of the city.

\section{b. Risk dynamics in the historic centre and periphery of Lima}

To look at the dynamics of risk investments at the local level, we draw on empirical data gathered with local communities during a two-year study in the settlements of Barrios Altos and José Carlos Mariátegui, respectively in the centre and periphery of Lima (Map 1). These areas were chosen due to their contrasting dynamics and different stages of urban development, while sharing underlying causes that increase low-income inhabitants' vulnerability and erode their capacity to confront environmental hazards. 


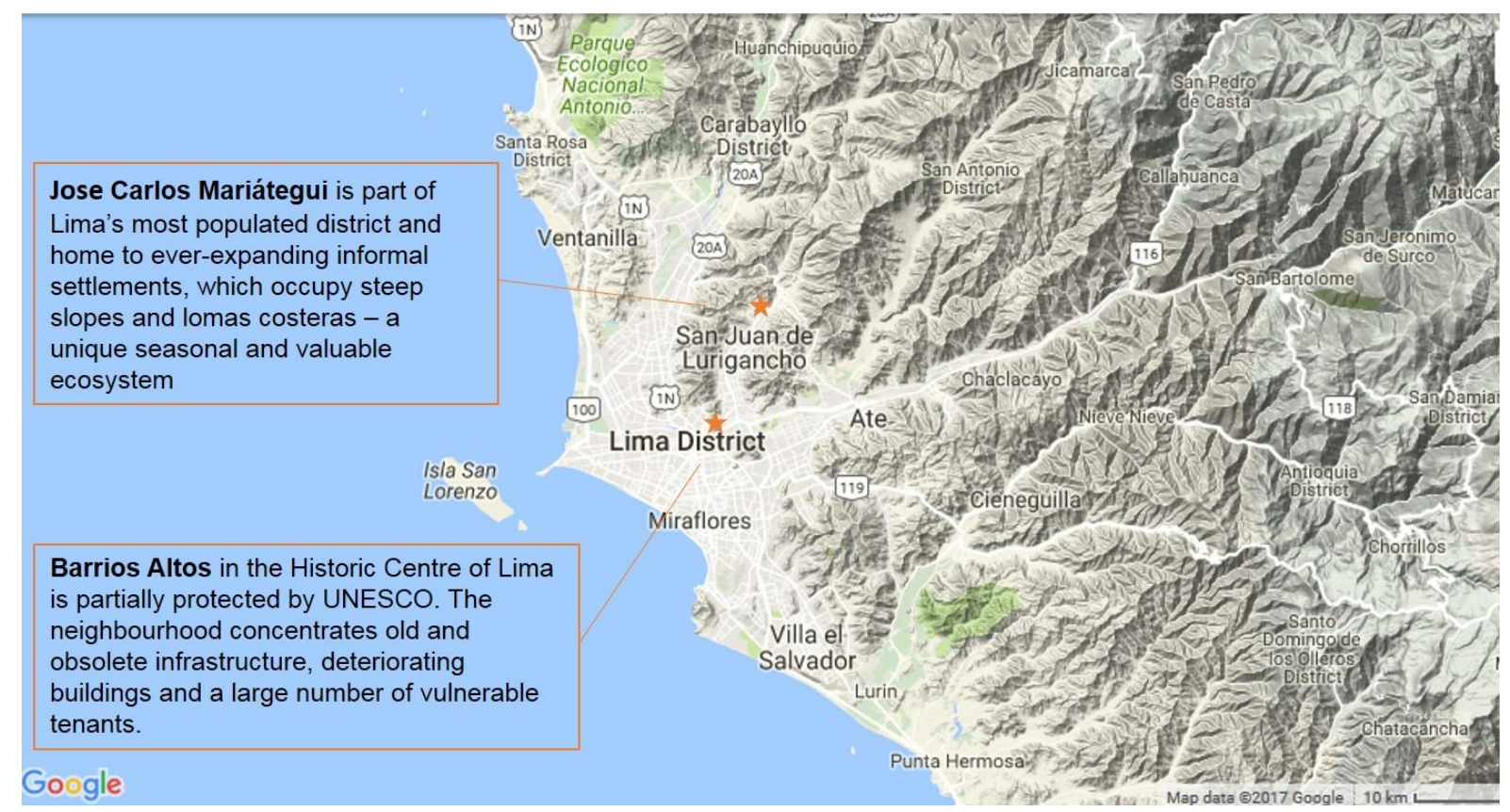

Map 1 Locations of the two case study areas, Barrios Altos and José Carlos Mariátegui, in Metropolitan Lima

NOTE: Lomas costeras are a unique seasonal ecosystem that covers the hills of the periphery of Lima with greenery in the winter months when the fog brings enough humidity to the area. The lomas are a critical part of Lima's ecological infrastructure that enhance the recharge of aquifers and help to regulate micro-climatic changes, two essential functions in a desert city.

SOURCE: cLIMA sin Riesgo on the basis of Google Maps (2016).

Barrios Altos is located in the district of Cercado de Lima in the eastern quarter of the city centre. Its historic importance for Lima was formally recognized through its declaration as a UNESCO World Heritage Site in 1991. However, the area is subject to a complex web of urban change processes, which happen behind the protected facades of colonial multi-family housing units called quintas (Photo 1). 


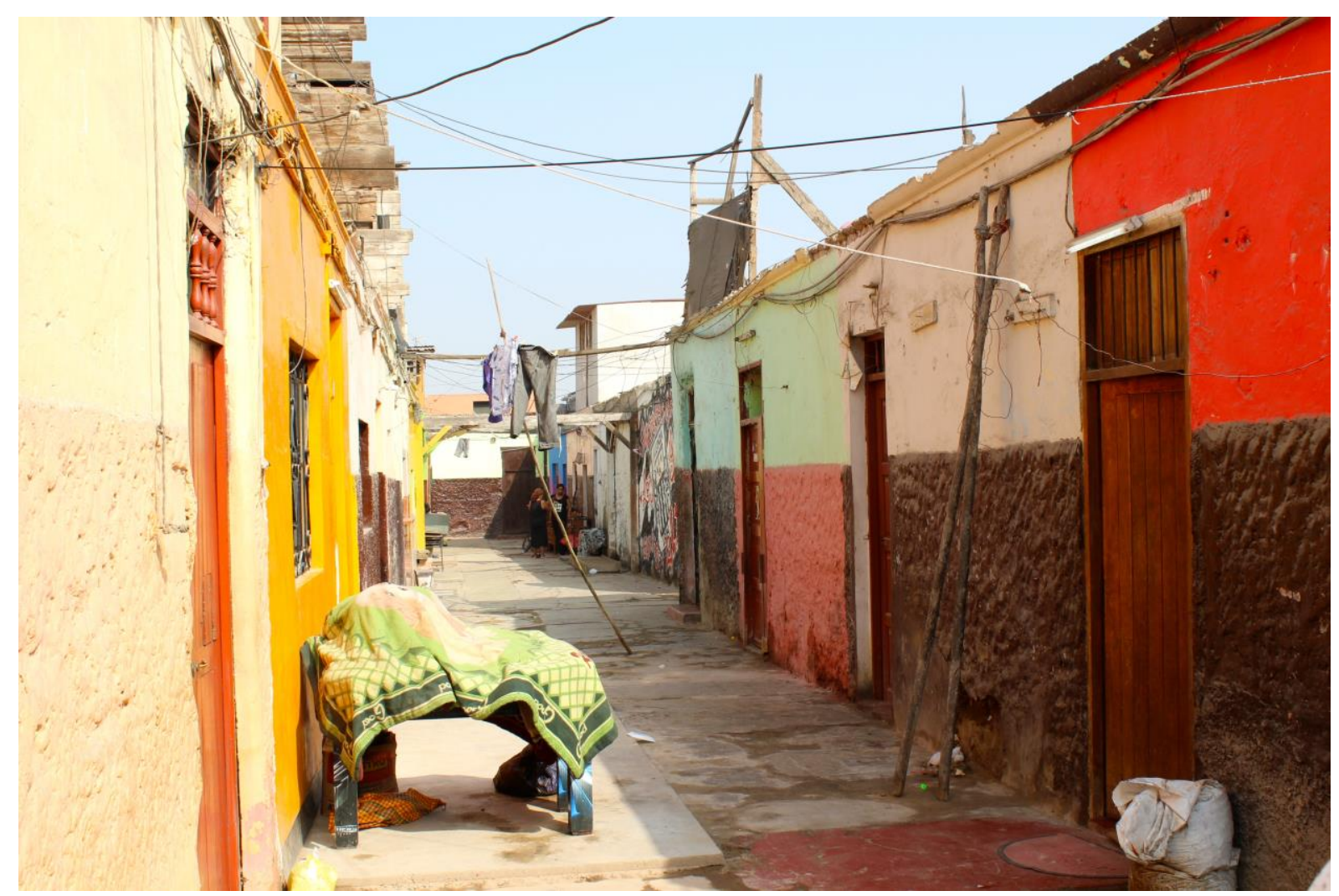

Photo 1 Communal Area within a quinta where each door leads to an individual housing unit, Barrios Altos

(C) R Lambert, cLIMA sin Riesgo (2015).

Over time, the quintas have been subdivided into multiple dwellings, predominantly occupied by low-income tenants, who often face eviction threats due to their insecure tenancy rights. Although quintas vary in size, on average about they include about 26 housing units, which host about 33 households. Unsafe housing conditions such as broken water and sewage pipes, poor electricity connections that lead to frequent fires, and collapsing buildings are manifestations of ongoing deterioration.

INEI statistics ${ }^{(24)}$ show that the population in the Cercado district decreased from 322,597 inhabitants in 2005 to 271,814 in 2013 . The slow and steady deterioration process and forced outmigration of low-income families is tightly linked to rapid land use change and property speculation in the area. Private developers convert residential housing units - often without permission - into lucrative commercial storage units, which are in high demand due to the strategic location of Barrios Altos close to central markets. Indicators of this process include the number of new water and electricity installations, which from 2002 onwards exceeded the number of incoming residents and therefore show the gradual decline in residential use.

Individual households and community organizations in the quintas are forced to make frequent investments to reinforce building structures, repair sewage pipes, and connect their dwellings to electricity. However, these collective and individual efforts at best slow down processes of deterioration and further risk creation, without tackling the root problems of the rapid transformation of the neighbourhood from a historically protected residential area into a privatized market are of storage units, warehouses and gas stations.

Located in San Juan de Lurigancho, Lima's most populated and poorest district, José Carlos Mariátegui was founded in the early 1990s through collective processes of land invasion. Currently it comprises 13 informal settlements, collectively organized through so-called Agrupaciones Familiares (AF), or family-based groups (Photo 2). 


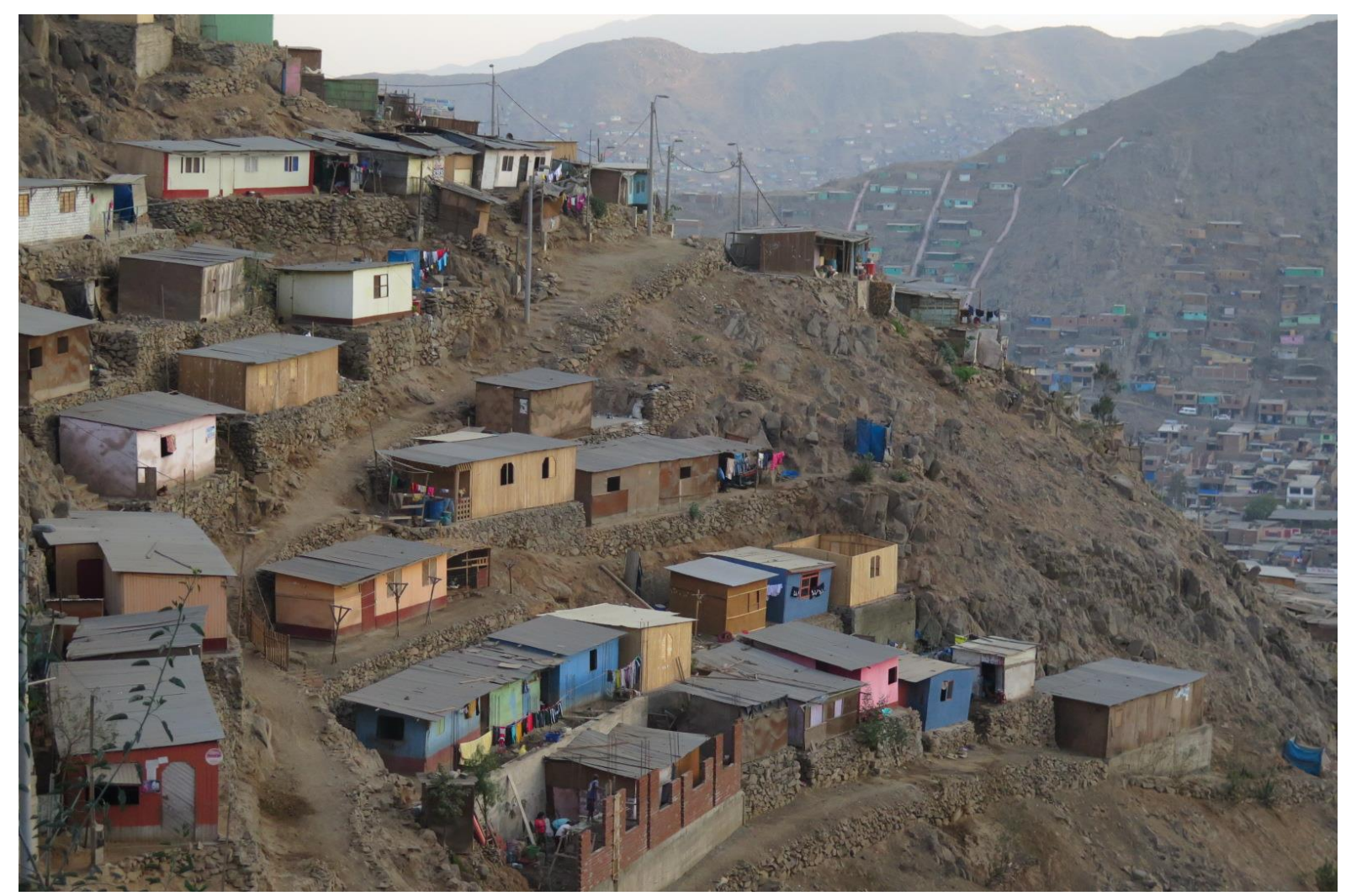

Photo 2 Expanding settlements on the slopes of José Carlos Mariátegui

(C) A Allen (2015).

Processes of land occupation in this area have been referred to as the "expansion of the expansion", describing a repetitive pattern of urbanization that constantly reconfigures the periphery of the city. While the first settlers invaded the lower parts of the area's slopes, recent newcomers are attracted to the upper hillsides by a combined process of gradual "pirate" land subdivision driven by the established Agrupaciones Familiares, and the activities of external land traffickers, who profit from the illegal acquisition and sale of plots. New settlers often arrive in José Carlos Mariátegui, drawn by the low cost of accessing land there as well as the legal and economic impossibility of accessing housing for current and future generations elsewhere. However, the initial economic feasibility has to be juxtaposed with the investments required to adapt to the conditions of the terrain, to access basic - though highly inadequate - water, sanitation and electricity services, and to obtain some form of legal recognition, which is crucial for avoiding eviction and entitling residents to interact with state agencies. Precarious living conditions lead to frequent accidents due to rock falls and strong winds; injuries due to poor accessibility; respiratory and gastro-intestinal illnesses; and fires. Importantly, these risks do not manifest themselves in isolation, but often converge over time, trapping the most vulnerable households in a complex web of threats.

Findings from the cLIMA sin Riesgo survey and a study by Quispe Romero and Arias Ävila, ${ }^{(25)}$ on housing in the area, reveals that it takes most Agrupaciones Familiares between 8 and 15 years to transition from land occupation to the acquisition of some form of basic infrastructure, a period during which, in particular, newly arriving young families and single mothers with children face perilous living conditions and find it difficult to avert risk accumulation cycles. ${ }^{(26)}$ Moreover, a closer look at the living conditions of the most vulnerable households - such as female-headed households with high socioeconomic dependency ratios - reveals that for many, even achieving the most basic improvements over time is elusive, as their efforts and investments are repeatedly hijacked by risk-coping interventions. This in turn makes these households dependent on help from external organizations and the widespread practices of political clientelism reinforced by the state. 


\section{STATE-LED PROGRAMMES AND BUDGETS TO ADDRESS URBAN RISKS}

Several state-led programmes and budgets, which fully or partially, explicitly or implicitly target disaster risk management, emerged with the establishment of the National System of Disaster Risk Management (SINAGERD). One key programme is the Budget for the Reduction of Disaster-Related Vulnerability and for Emergency Response (Programme PP-0068), established in 2011 within the Ministry of Economy and Finance (MEF) to reduce disaster risks and respond to diverse natural hazards such as flooding, earthquakes, landslides, and low temperatures. The programme budget is distributed among three levels of government, with an allocation of 44 per cent to the regional and local governments and 56 per cent to the national government. In the period 2011-2015, US\$2,192 million $^{(27)}$ was dedicated to this programme.

The so-called "General Law on the National System of Indebtedness" enables the national government to contract contingent loans and other instruments to mobilize resources in the event of a natural or technological disaster and to mitigate risks in emergencies. In December 2015, the national government held specific contingent credit lines from several bi- and multilateral international agencies, such as the Andean Development Corporation, the Inter-American Development Bank, the Japan International Cooperation Agency, and the World Bank for adverse events related to El Niño. Further, an emergency decree (No. 004) was issued in 2015 to allow the national government to shift resources to implement disaster prevention related to expected heavy rainfalls in 2015-2016. This decree resulted in US\$ 469 million allocated to support health infrastructure and to maintain riverbeds and valleys to avert the impact of heavy rains and flooding, as well as to carry out flood monitoring, prevention campaigns, and investment in equipment and early warning systems.

The year 2016 saw the inclusion of El Niño-related expenses in the public sector budget, and the national, regional and local governments were allocated a total amount of US\$ 303 million for immediate actions in response to El Niño, of which 83 per cent had to be spent through the PP-0068. At the same time, a contingency budget of US\$ 868 million was earmarked for response, recovery and reconstruction actions after El Niño phenomena. All this indicates that, in recent years, the Peruvian government has made significant efforts to respond to changing environmental conditions that might contribute to large-scale disaster events.

Further, two national programmes have been identified, which are not defined as disaster risk management programmes, but which earmark parts of their budgets for DRM activities. These are the programme PP-0073 Trabaja Peru, which aims to reduce socioeconomic vulnerability through inclusive employment, and which implemented 305 projects between 2011 and 2015 with a total value of US\$14,430,000; and the programme PP-0108 Mejoramiento Integral de Barrios, which aims to bring integrated improvements into low-income neighbourhoods, with a total investment of US\$ $4,724,150$ in five projects over the same time period.

Within the Metropolitan Municipality of Lima (MML), over 12 per cent of a total municipal budget of US\$ 546,844 million allocated between 2011 and 2015 was directly targeted towards disaster risk protection, 4.23 per cent to improve poor accessibility and 0.56 per cent to improved water and sanitation services. While investments in the latter two areas are crucial to decrease smallscale and everyday risks, the bulk of metropolitan expenditure ( 45.33 per cent) was dedicated to road works (Figure 2). These allocations reflected the municipal strategy to prioritize road works and transport infrastructure; a failure by authorities to see disaster risk management as integral to managing development; and the authorities' disproportionate attention to mitigating the impact of disaster events over disaster risk reduction and prevention. 


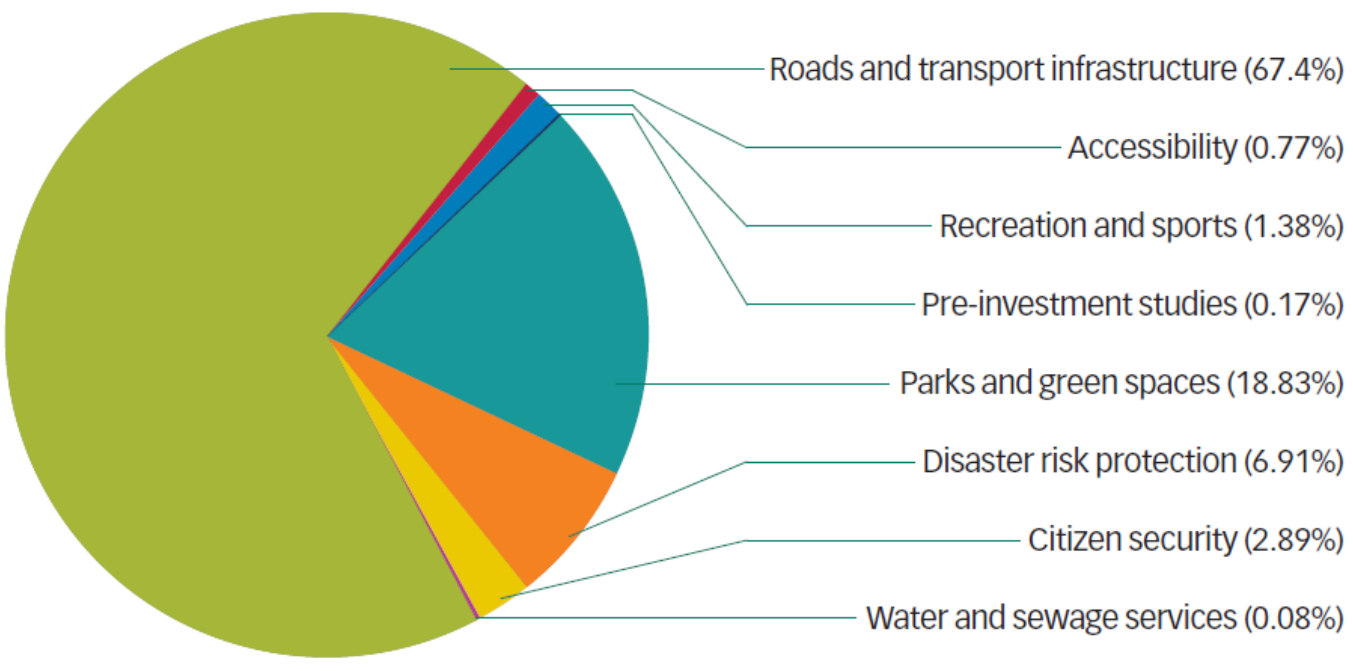

Figure 2 Implementation of budgetary resources within San Juan de Lurigancho, the district containing José Carlos Mariátegui, over the last five years

SOURCE: Translated from Ferro, V (2016), Public Financing of Disaster Risk Management (in Spanish), Internal report prepared for the cLIMA sin Riesgo project, Lima. Elaborated for the cLIMA sin Riesgo project.

Investments made at the district level show a similar distribution and set of priorities. In the peripheral district of San Juan de Lurigancho (SJL), where José Carlos Mariátegui is located, just 6.91 per cent (US\$ 2.74 million) of the local government's total budget was spent on disaster risk management, 0.77 per cent on improving accessibility, and only 0.08 per cent on water and sanitation services.

The background material on Barrios Altos and José Carlos Mariátegui has already elaborated on the need for spatially and socially targeted efforts to address highly heterogeneous conditions of risk production and reproduction in the centre and periphery of Lima. However, an evaluation of the actual destination of public investments in the two study areas is hampered by the lack of official records monitoring such investments beyond the district level.

In José Carlos Mariátegui, the programme Barrio Mio, which aimed to stabilize the slopes in risk zones, was the only project implemented during the period 2011-2015, with an investment of US\$ 91 million. In relation to DRM investments, the district San Juan de Lurigancho, which is home to about 10 per cent of Lima's population, benefitted from only 3.8 per cent of the total riskmitigation investments devoted to the whole of Metropolitan Lima over the same period.

Over the same period, in Barrios Altos, just over US\$ 16.8 million was spent by the district government, mostly on crime reduction (33 per cent) and road infrastructure projects ( 26 per cent). Even though people live in conditions of high risk in this area, no resources were allocated to vulnerability reduction and the protection of the inhabitants between 2011 and 2015. ${ }^{(28)}$ Before that, local public investments in disaster risk management were also limited to exceptional programmes such as Mejorando Mi Quinta, which between 2007 and 2010 undertook US\$ 150,000 worth of interventions in 15 to 20 quintas in the historic centre.

The gap in addressing extensive risk also becomes visible in the provision of basic services. For example, the state water utility SEDAPAL provides and maintains infrastructure only up to the entrance of each quinta, but does not provide services or individual household connections inside the multi-family units. Similarly, the private electricity provider EDELNOR only provides collective supply points, which means that tenants themselves have to manage installation of household connections. The Charity Society of Metropolitan Lima - known as "Beneficiencia" - owns a large number of properties and has the task of supporting housing for the most vulnerable people, but it does not have sufficient resources to properly maintain the estates. 
In sum, it can be argued that policies, programmes and projects from the different "external actors", such as private and public service providers and civil society organizations, are practically irrelevant for risk reduction in these specific locations, thereby putting the burden of investments on inhabitants' individual and collective actions.

\section{METHODOLOGY: ASSESSING LOCAL RISK INVESTMENTS AND URBAN RISK TRAPS}

To get a detailed understanding of the spatial and temporal patterns of risks traps and resources invested by inhabitants in response to deficient or non-existent government investments, in-depth georeferenced surveys were conducted between July and September 2015. ${ }^{(29)}$ Data were gathered at the household level in both case study areas, as well as at the multi-family housing unit or quinta level in Barrios Altos, and at the settlement level in José Carlos Mariátegui.

Generic socio-demographic questions were directly aligned with the surveys conducted by the Peruvian National Institute of Statistics and Information (INEI) to allow for comparison of the settlement data with existing official data. The survey questionnaires included social and economic variables that reveal levels of vulnerability, risk perceptions, experiences of the manifestations of risks, and capacities to act, the latter indicated for example by the individual and collective savings capacities and frequent investments devoted to coping with different risks. The questionnaires were complemented by direct observation of physical aspects such as housing condition and construction materials, types and condition of available infrastructure and services, and the specific hazards that affect each area. Data were georeferenced using the smartphone app EpiCollect+ and, once cleaned and processed, uploaded in ReMapRisk, a tool developed by cLIMA sin Riesgo. The tool allows users to document and monitor how and where risk accumulation cycles or "urban risk traps" materialize over time, feeding spatial and temporal details into an interactive online database about specific hazards, who is affected, where, how and why. ReMapRisk also allows public enquiries into the information stored on the online database events, and produces maps at different predetermined scales in response to each enquiry.

The sample of Barrios Altos included 40 blocks, within which 158 quintas (30 per cent of the multi-family units inhabited in each block) were surveyed. A further 187 household surveys were conducted in 25 selected quintas, chosen to capture a diverse profile of tenants with different levels of legal and physical (in)security, because tenancy arrangements were previously identified as crucial components to explain urban risk traps in the area. With the inclusion of these selected quintas, the survey was able to gather data on multi-family housing units that were: (a) declared uninhabitable by the municipality; (b) declared as tugurios (dwellings in overcrowded and deteriorating conditions,; (c) declared as historic heritage sites; (d) targeted by municipal urban renewal programmes; and (e) a random selection of housing units to cover the remaining percentage in each block.

In José Carlos Mariátegui, 11 settlements in three valleys, which join at a main road, were chosen for their different patterns of consolidation and ongoing expansion in the periphery. Surveyed settlements uphill are characterized by their recent occupation and are undergoing rapid expansion, while those closer to the main road and at the foot of the slopes had a longer history, visibly manifested in better housing conditions and access to basic services. Within the settlements, the survey covered 30 per cent of the occupied plots in each settlement, reaching 350 randomly selected households living under different levels of exposure and vulnerability to risk across the steep slopes. Preliminary results of the surveys were presented and discussed with local dwellers and community organization leaders in two workshops in March 2015. The analysis in this paper focuses primarily on those questions directly addressing risk investments and capacities to act, while questions characterizing general conditions provided context, explaining how these capacities to act fit into the wider concept of urban risk traps.

Several cautions on the methodology emerged after an initial analysis and workshop feedback, which give the following results an indicative rather than definite value. Importantly, living at risk is a condition that many inhabitants of Barrios Altos and José Carlos Mariátegui have normalized and internalized. For instance, those interviewed often claimed not to have devoted any resources to mitigate particular threats, though their answers to other parts of the questionnaire often reveal recurrent investments made to build retaining walls or enhance the durability and resistance of 
housing components. Furthermore, many respondents clearly recalled their experience of being affected by a small-scale event. However, they often found it difficult to recall the frequent investments made in recovery, as the boundaries between recovery from an event and actions to improve living conditions become blurry. Additionally, answers related to structural and regular investments like those dedicated to housing improvements and procurement of medication produced more coherent data, as compared to small investments that are regarded as extraordinary. For example, recalling the frequency of investments in medication for skin diseases and respiratory problems was easier than of those made for smaller repair works after rock falls.

\section{COMMUNITY-LED INVESTMENTS TO MITIGATE RISK}

The previously mentioned study by CENCA (Instituto de Desarollo Urbano) on community-led investments in the upper parts of JCM found that residents contribute on average 87 per cent of the total costs to improve the area, the state 8.3 per cent and service-providing companies 2.1 per cent. ${ }^{(30)}$ As already explained, these expenditures include fees to attain some form of tenure security, and costs to access potable water and improve accessibility and mobility. Hence, while the initial cost of accessing a plot on the slopes is relatively low, significant investments are required progressively and over long periods, as residents cannot access the formal market because they neither have large sums of money nor fulfil the eligibility criteria for obtaining credit.

About 22 per cent of the surveyed houses were classified - based on observations and household information - as being in danger of collapse; only 5 per cent were found to be in good condition. Only three of the 322 surveyed households were found not to be exposed to any of the multiple threats related to housing conditions, including unsafe access roads, high levels of humidity and precarious housing conditions. This suggests that most of the investments that people made when moving into the area did not have an impact sufficient or sustainable enough to affect housing quality or to mitigate risk. When this information is put into the context of the year of arrival in the area and basic investments to consolidate the neighbourhoods, it becomes obvious that recent settlers on the steeper slopes live at higher risk than the ones in more developed and flatter areas (Figure 3 and Map 2). 


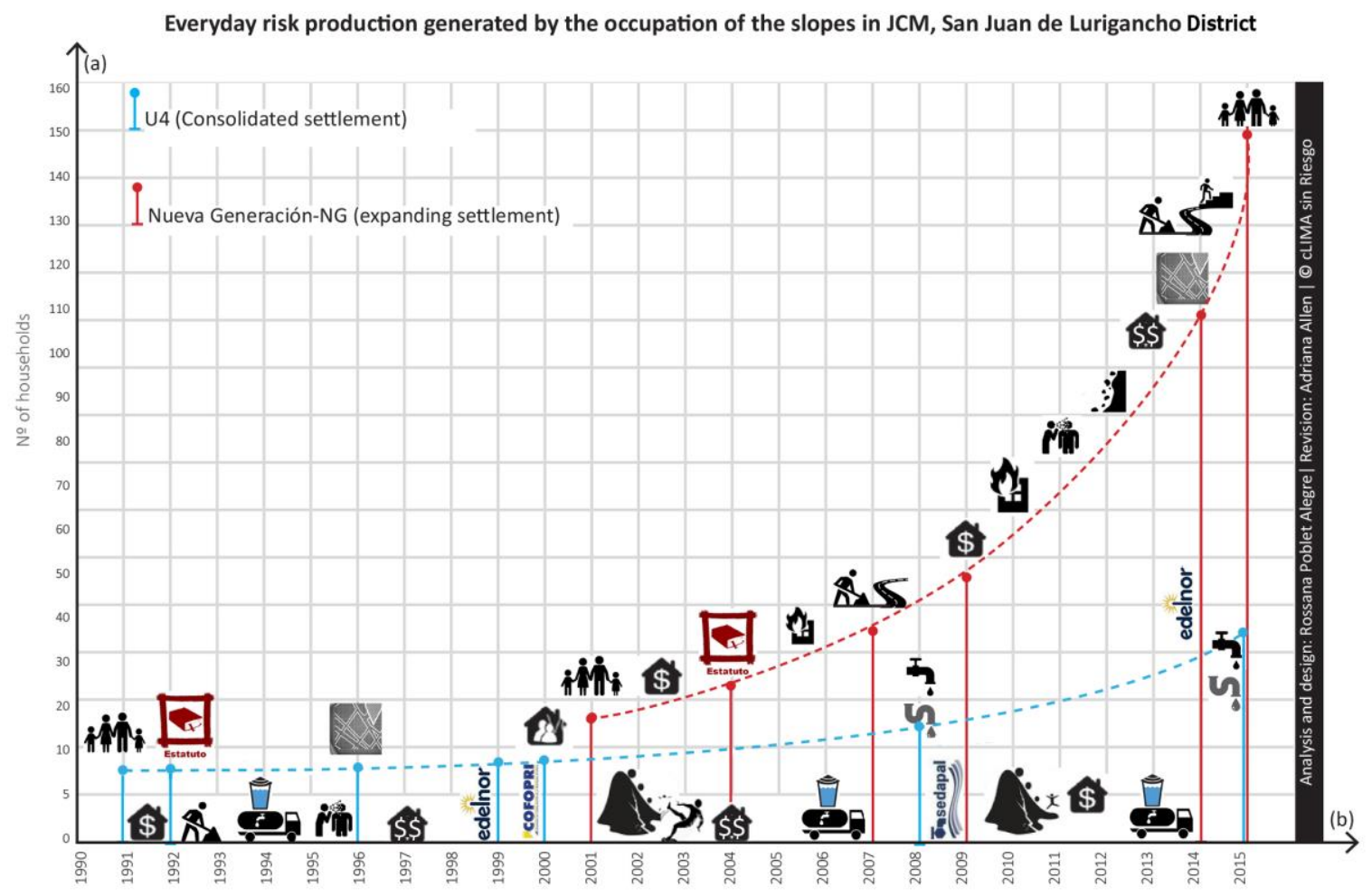

Year

Habitat construction at settlement and household level
Arrival of families
and self-organisation

Figure 3 Settlement timeline of two Agrupaciones Familiares in JCM showing the growth of households $(y-A x i s)^{(a)}$ and investments made by local residents over time to ameliorate their living conditions, as well as their everyday and episodic events that set them back in their efforts $\left(X\right.$-axis) ${ }^{(b)}$

\section{NOTES:}

(a) The relatively small number of households organized in Agrupaciones Familiares (AF) in consolidated areas reflects the fact that, once services are collectively attained in the lower parts of the settlement, mobilization to secure further services and improvements in the upper parts of the slopes slows down. As a result, those dwellers still living in unconnected areas tend to split the settlement, form a new Agrupación Familiar and renew their quest to ameliorate the area, while attracting further settlers to increase their critical mass and financial capacity.

(b) Although according to local community organizations rock falls do not appear to impact expanding settlements, reports from Civil Defence indicate that this type of hazard is frequently experienced in both the lower and upper parts of the slopes.

SOURCE: Based on the cLIMA sin Riesgo Settlements Survey 2015 


\section{Level of vulnerability according to type of water/ Year of arrival in JCM and dates the settlements}

sewerage connection and house condition were established
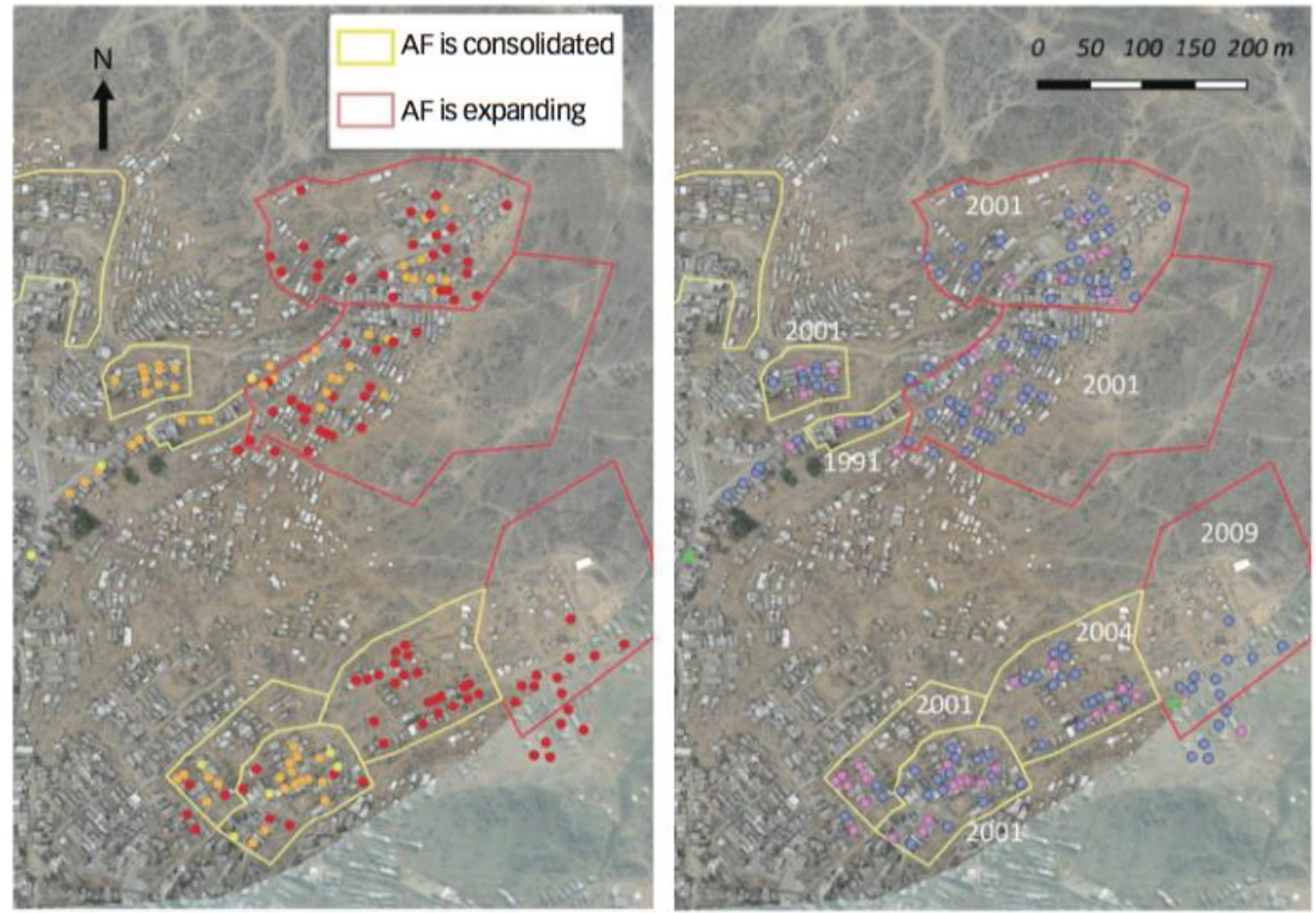

Before 1996 1997-2004 2005-2015

Level of vulnerability according to house condition

\begin{tabular}{|c|c|c|c|}
\hline Dangerous & High & High & $\begin{array}{l}\text { Very } \\
\text { High }\end{array}$ \\
\hline Requires improvement & Medium & High & High \\
\hline \multirow[t]{3}{*}{ Satisfactory } & Low & Medium & High \\
\hline & Low & Medium & High \\
\hline & \multicolumn{3}{|c|}{$\begin{array}{l}\text { Level of vulnerability according to } \\
\text { water and sewerage connection }\end{array}$} \\
\hline $\begin{array}{l}\text { Does not have a latrine or } \\
\text { has a shallow latrine }\end{array}$ & High & High & Very High \\
\hline Only has a septic tank & Medium & High & High \\
\hline \multirow[t]{2}{*}{ Has a connection to a public utility } & Low & Medium & High \\
\hline & $\begin{array}{c}\text { Hasa } \\
\text { connection } \\
\text { to a public } \\
\text { utility }\end{array}$ & $\begin{array}{l}\text { Only has } \\
\text { water from } \\
\text { a public tap }\end{array}$ & $\begin{array}{l}\text { Only has } \\
\text { water from } \\
\text { neighbours }\end{array}$ \\
\hline
\end{tabular}

Level of vulnerability according to type of water connection

Map 2 Level of vulnerability according to the type of water/sewerage connection and house condition in settlements of José Carlos Mariátegui, with different stages of consolidation

NOTE:

$\mathrm{AF}$ - Agrupacion Familiar (family group)

SOURCE: Based on the cLIMA sin Riesgo Household Survey 2015. 
A clear contradiction is found here: whilst relatively small investments are required to occupy a plot of land - on average US\$180 - the necessary investments multiply over time, as settlers struggle to make the steep slopes inhabitable. These costs include those for flattening plots of land, gaining access to potable water, improving accessibility, and coping with the multiple everyday risks produced by the very effort to occupy the slopes. For those settled in the last five years, these costs amount on average to over US\$12,000. Considering that the average annual household saving capacity is below US\$330, this means that in effect newcomers need to go through a lifetime of investments to achieve very basic living conditions. As a result, small-scale disasters tend to accumulate and intensify over time, exacerbating the challenges faced by already impoverished and marginalized households, and pushing them further into "risk traps" that cannot be broken through individual efforts.

It is also important to highlight the heterogeneity within the area regarding people's capacities to invest. The survey revealed that most inhabitants living in the area are able to save a small amount each month, ranging from less than US\$ 5 to US\$ 50, while others borrow money from their families and moneylenders and a few have access to credit. Furthermore, investments in basic services are highly diverse across households and settlements in José Carlos Mariátegui, where 60 per cent of the settlers depend on communal water taps and 25 per cent on communal latrines. The quality of water and sanitation facilities was assessed on a scale from "dangerous" to "good", with highly diverse conditions for individual households" facilities, whereas communal facilities were largely found to be "dangerous".

The survey also highlighted uncertainty about what sustainable solutions to risk reduction and prevention might look like. While the amount of money that households can access logically defines their capacity to invest, even those at the higher end tend to focus primarily on short-term reactive measures, instead of investments that reduce and prevent risk.

Investments explicitly targeting risk management usually have low priority among the inhabitants compared to investments in basic needs. For example, 34 per cent of the surveyed households reported being affected by rock falls due to the instability of the terrain, bad construction of retention walls and walls of their houses, dampness and poor road construction on steep terrain. Despite this experience and resulting damage, only 11 per cent have invested in preventive measures to reduce this risk.

It is worth mentioning that there are collective practices in José Carlos Mariátegui that go beyond financial investments. The so-called communal faenas are working routines that aim to improve the built environment and support the settlements. Two-thirds of the surveyed households regularly participate in these faenas, which include risk-mitigating activities addressing mostly structural improvements to prevent rock falls and accidents on the access paths as well as the collapse of stone walls. These and other individual and collective activities performed by the inhabitants of JCM to cope with risk are schematically outlined in Figure 4 and compared to the previously mentioned state-led investment actions. 


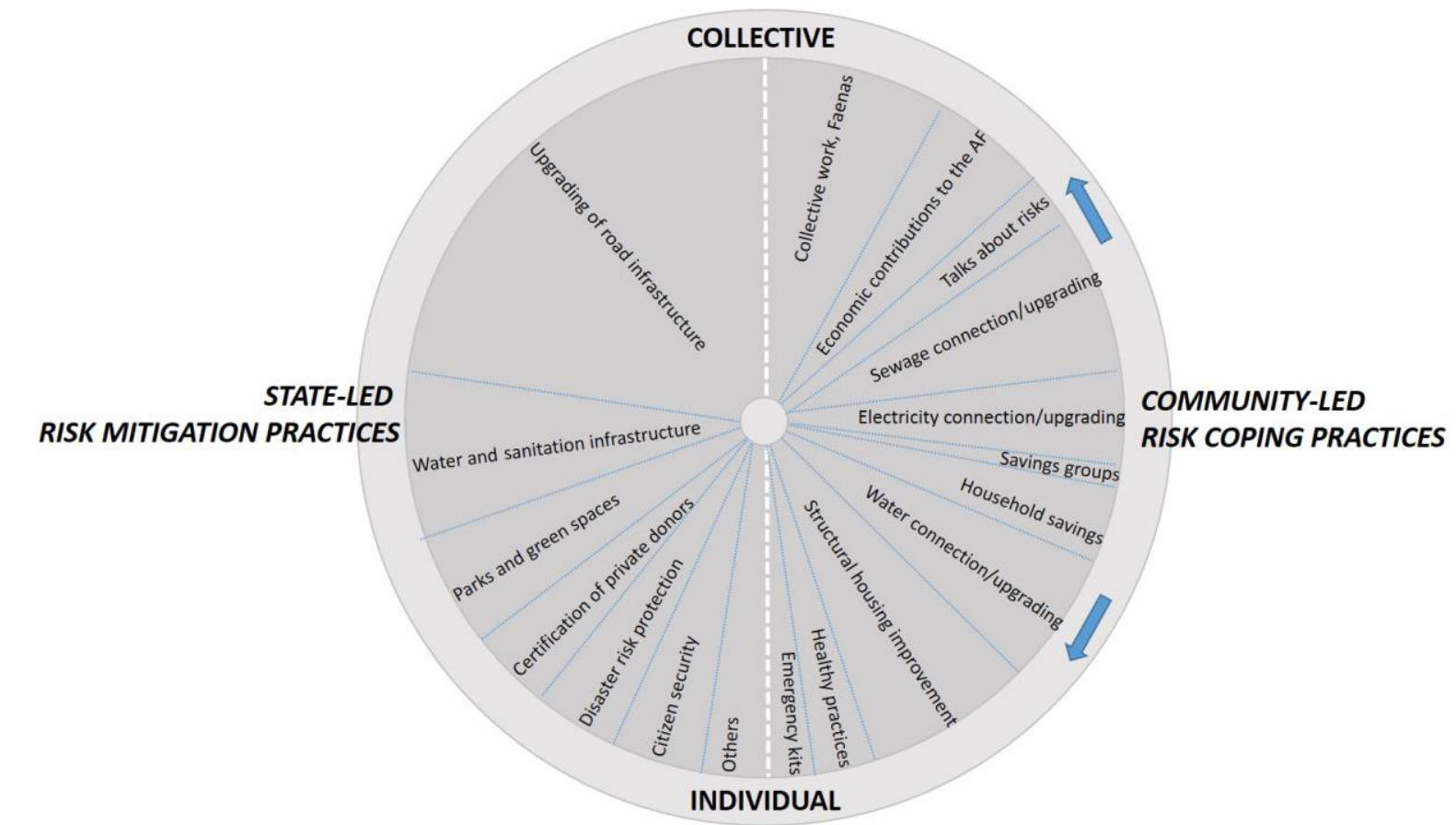

Figure 4 Collective, individual, community and state-led risk management practices in José Carlos Mariátegui

\section{NOTES:}

The sizes of the pie slices indicate the resources devoted to each practice. AF= Agrupación Familiar (family group)

SOURCE: cLIMA sin Riesgo project.

In sum, the survey revealed a wide diversity of investment actions taken by residents to access the slopes and incrementally improve living conditions. While there has been a pattern in the way newly arriving settlers have consolidated the area since the 1990s, the investments made collectively and individually by old settlers only managed to mitigate everyday risks on a highly localized basis, while reproducing further risks in the upper part of the slopes (Photo 3). This is locally described as "urbanization in hope", meaning that newcomers settle in areas of high risk under the hope that over the years they will be able to attain the same improved living conditions secured with sacrifice by earlier settlers. Unfortunately, for new households, risk trajectories become deeply entrenched and further erode their capacity to contribute to long-term risk reduction and more sustainable urbanization processes in the peripheral settlements. 


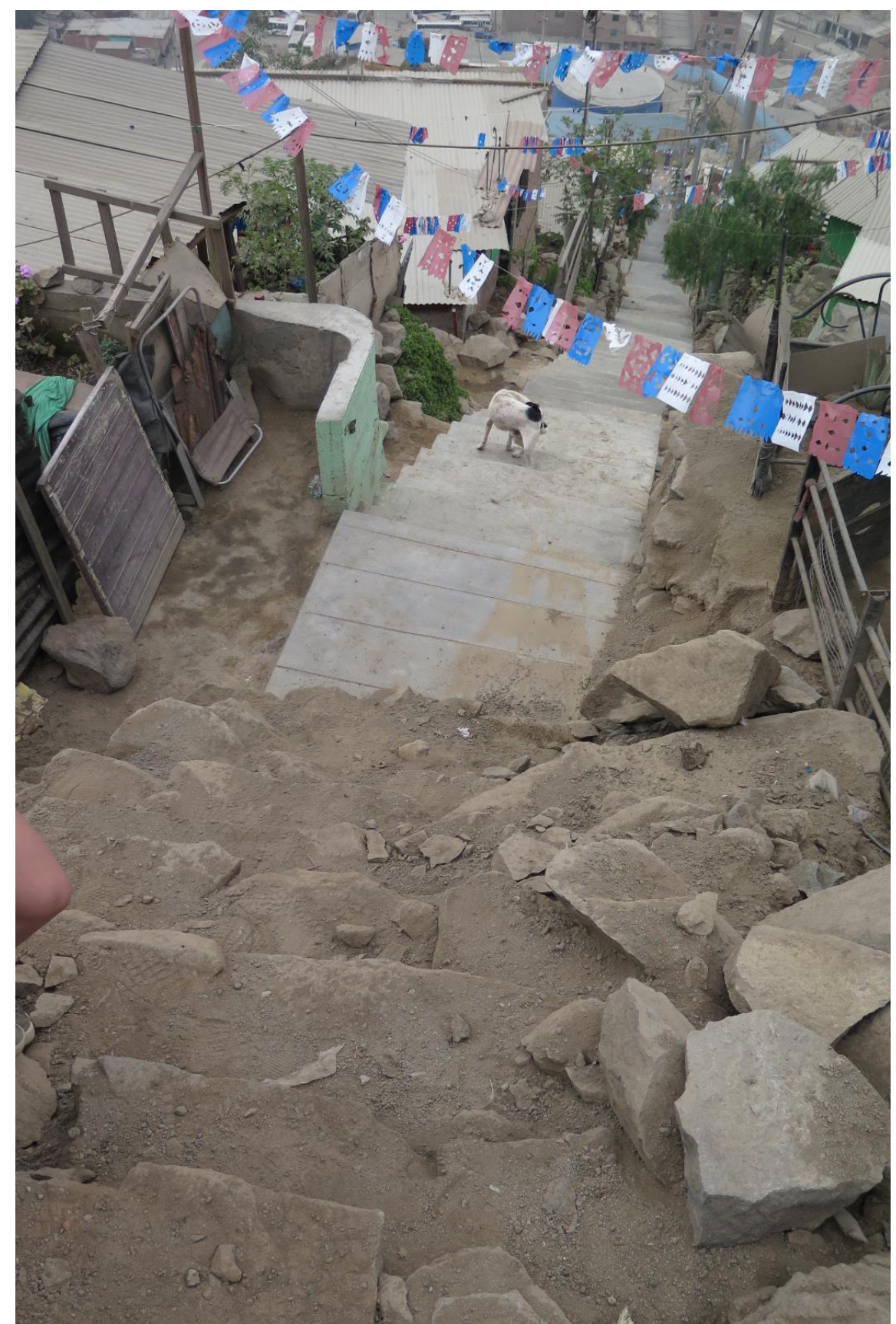

Photo 3 Community-led investments to improve accessibility in the lower parts of the slopes in José Carlos Mariátegui

(C) A Allen (2015).

In Barrio Altos, in the historic centre of Lima, 90 per cent of the surveyed households arrived in the neighbourhood before 2000, and residents have lived in the area an average of 32 years. This means that people have participated over an extended period in social struggles for dignified housing and neighbourhoods, and in activities to fight against land speculation, the threat of evictions and, in recent years, the increasing presence of storage facilities and warehouses that occupy a major part of the neighbourhood.

The survey found that in a quarter of the quintas there were mixed land uses, confirming the encroachment of for-profit uses of the buildings and the convergence of a high number of associated risks affecting many surveyed households (Map 3). It also revealed recurrent small, individual and separate investments undertaken by local dwellers that deplete people's resources without translating into long-term risk mitigation. For example, 68 per cent of the households frequently experience flooding inside their houses due to blocked or broken pipes. This causes dampness, bad smells, 
damage to the floors, and contamination. About 58 per cent of the households reported repeatedly investing in improving their sewage connections; however, 17 per cent had experienced serious problems due to leaking, blocked or broken sewage pipes over the past two years alone. Furthermore, 25 per cent of surveyed households stated that they have to invest frequently in repairing pipes and addressing this threat; another 25 per cent had to make seasonal investments. While most affected households and quintas were at least able to partially recover from damage after pipes were blocked or broken, 69 per cent of all surveyed households reported having no capacity to save money at present. This indicates that small amounts are frequently spent on coping actions to address urgent demands, whereas the larger individual and collective investments that are necessary for more longterm and sustainable solutions are beyond local investment capacities.

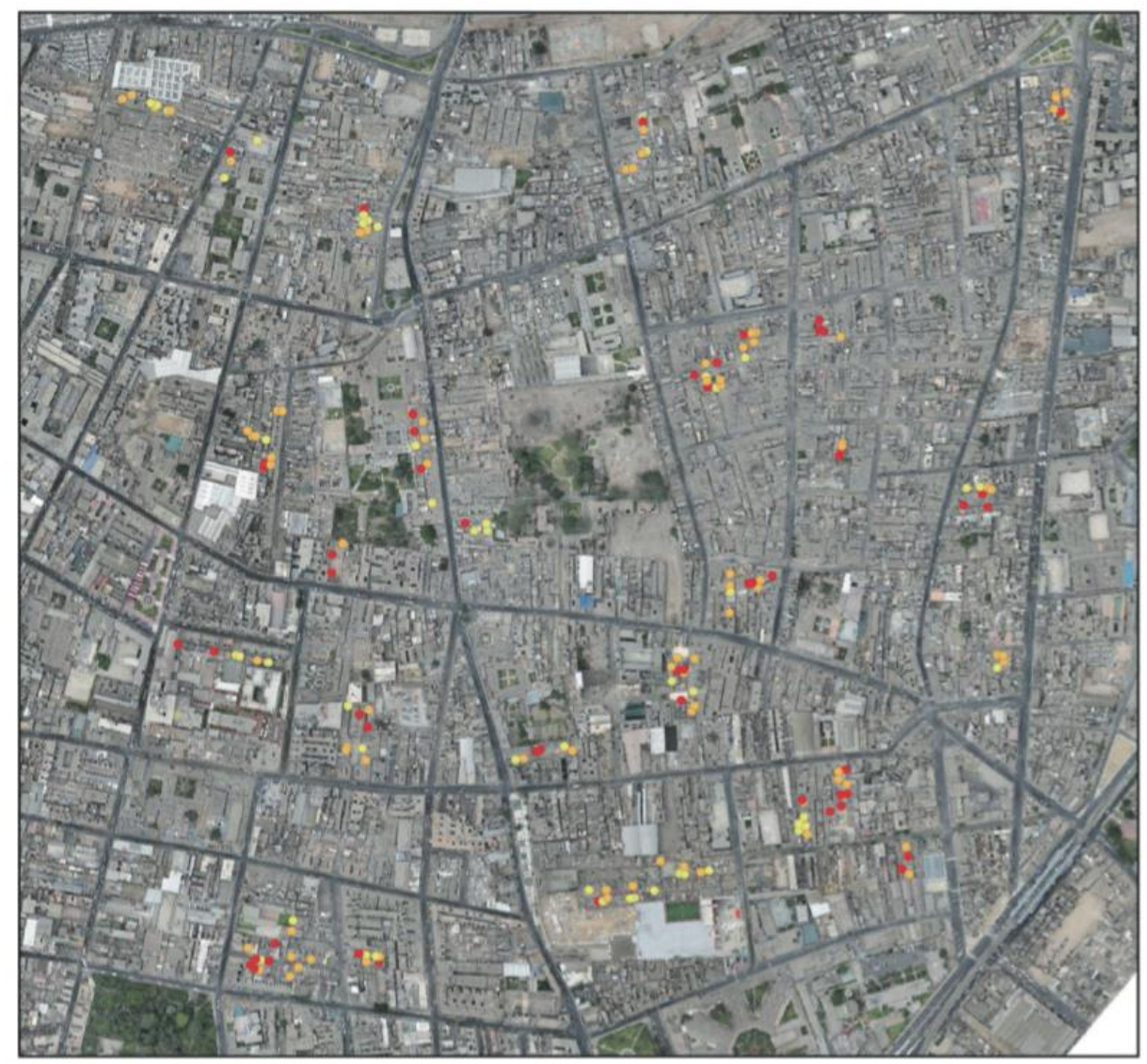

Level of risk experienced and frequency of risk

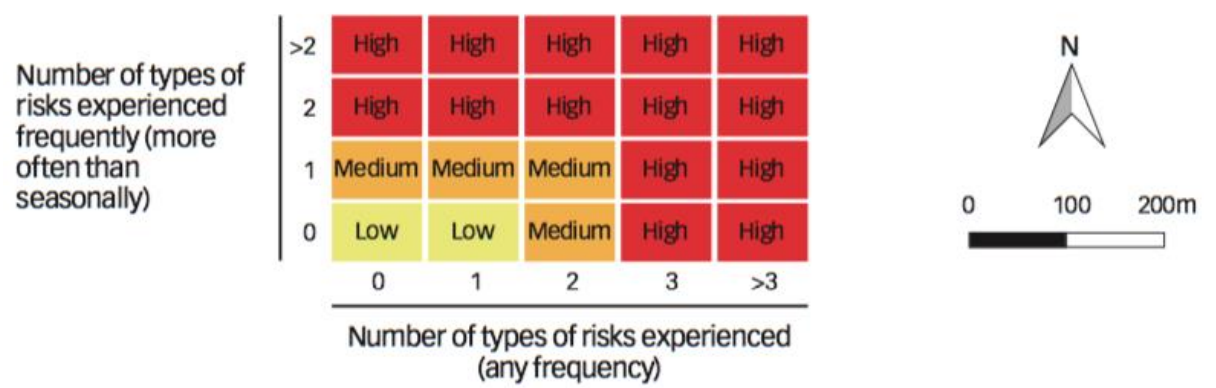

Map 3 Level and frequency of risks experienced by the surveyed households in BA

SOURCE: Based on the cLIMA sin Riesgo Household Survey 2015.

Women head almost half of the surveyed households. While the percentage of these households with the ability to save money is slightly lower than that of male-headed households (30 per cent as opposed to 32 per cent), female-headed households saved more on average per month 
(US\$ 80 as opposed to US\$ 72). In the workshop, participants emphasized that women are mainly responsible for saving money and handling investments.

Residents of the quintas who are organized into housing associations often implement collective events, such as communal meals and fairs, to raise funds for building improvements and maintenance. They also collect monetary contributions from each household to maintain or improve infrastructure. In 71 per cent of the quintas, families manage to generate funds to implement improvements and invest in common areas, as well as in water and sewage connections (Photo 4). However, the survey results did not show a clear correlation between the level of organization of the quintas and their experiences with risks, their ways to collect funds, and the investments made. Those participating in the devolution workshop questioned this finding and believe that organized quintas are more successful in generating funds and implementing successful improvement works.

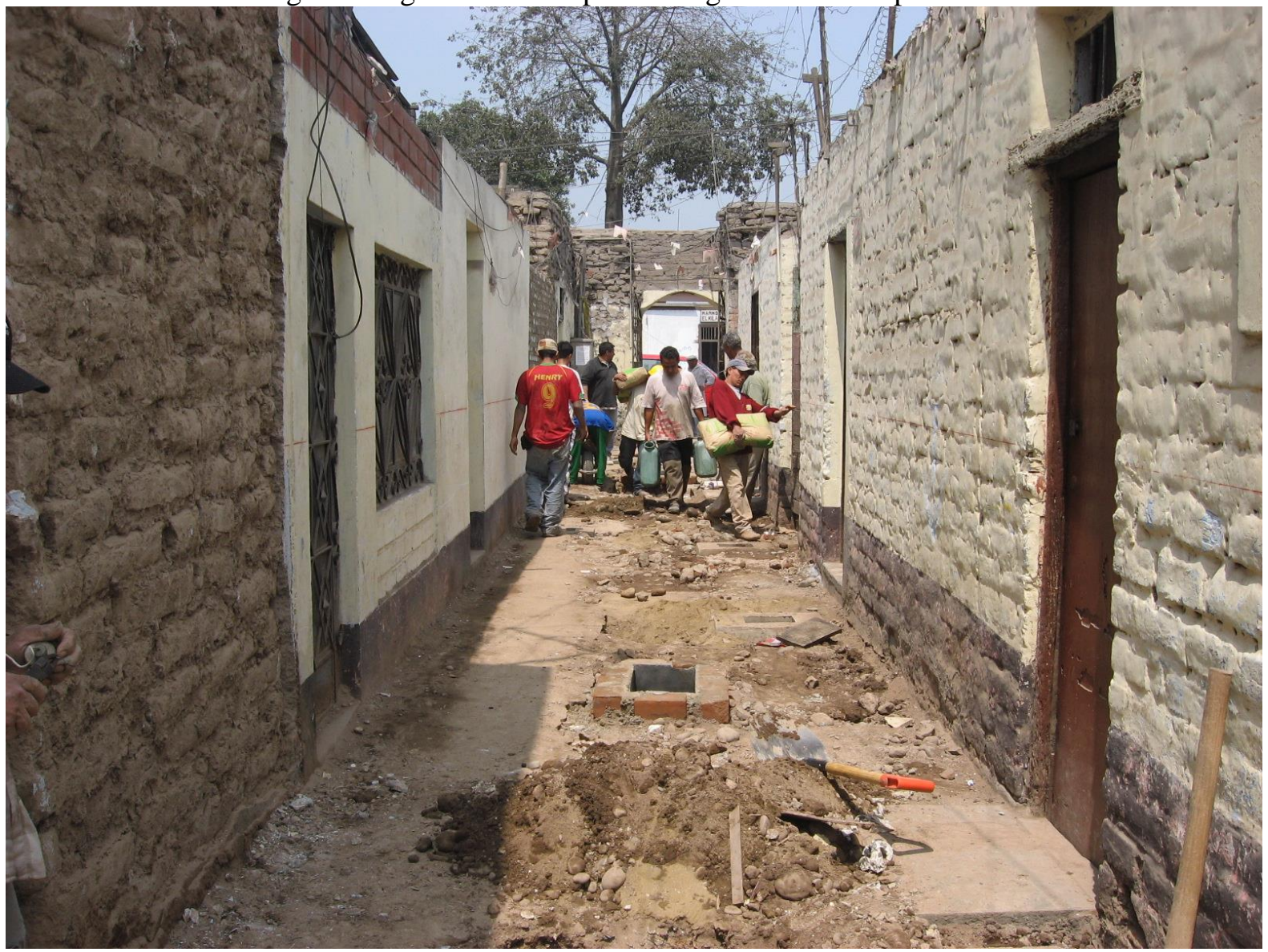

Photo 4 Collective investments inside a quinta in Barrios Altos to extend water and sewage connections to each dwelling

(C) T Belkow (2015).

The workshop participants further highlighted the importance of self-construction and selfmanagement for achieving more sustainable risk mitigation in the quintas and households. They also clearly voiced the need for more government support, from both municipal and national levels, to recover from damage, to drastically improve the living conditions in Barrios Altos, and to get rid of the stigma associated with an insecure and constantly deteriorating area. Despite the recurrent smallscale investments undertaken individually and collectively to cope with manifestations of risks, this deterioration continues.

\section{CONCLUSIONS: INVESTMENTS TO DISRUPT URBAN RISK TRAPS}

By looking at risk investments from the local to national scale and how they relate to urban risk traps in two settlements of Lima, this paper unpacked how factors such as environmental degradation, limited planning and lack of proactive management of the city, poverty and inequality, as well as 
highly limited access to land, basic services and adequate housing, jointly create adverse urbanization patterns. These reinforce biophysical and socioeconomic threats and vulnerabilities, which in turn contribute to the reproduction of processes of urbanization in conditions of risk, generating skewed cycles of displacement and exposure.

We argue that it is important to consider synergies in dealing with disaster risk reduction, climate change, and vulnerability to everyday risks and small-scale episodic disasters when conceptualizing and implementing processes for sustainable urban development. The convergence of extensive risks associated with low-severity and high-frequency events and intensive risks associated with major hazards contributes to the accumulation of risk. Without a long-term perspective on how urban risk traps operate, state responses are likely to continue focusing on large-scale disasters, missing the invisible and slow violence of risk traps that affect a sizeable percentage of impoverished women and men.

Further, the analysis of government policies shows that there are national plans and programmes that have not yet been sufficiently adapted to address local problems. Although a proactive legal and procedural framework has been in place since 2011 to shift from disaster risk management to disaster risk reduction and prevention, the capacities of local governments need to be enhanced and resources further decentralized to actually implement allocated budgets and reach target groups in a more effective way.

On a methodological note, risk data management systems in Peru are still in the process of development at different government levels. We argue that such systems need to involve local communities in the production, management and control of detailed risk data, not as simple collectors but under conditions of parity of participation. Furthermore, indicators to measure the impacts of DRM public investment have to go beyond quantifying economic losses and the cost of post-disaster recovery measures to weighing the benefits of risk reduction and prevention investments to improve the quality of the built environment and living conditions of the urban and peri-urban poor.

Community-based data and knowledge production can allow policymakers to better capture the experiences, perceptions and capacities to act of those at risk. They can therefore contribute to improving the design and targeting of state investment programmes and the evaluation of the impacts they have on everyday and small-scale risks in Lima's settlements.

At first glance, the analyses of Barrios Altos and José Carlos Mariátegui provide a bleak picture. While inhabitants and groups in both settlements invest implicitly and explicitly in risk mitigation, because of a lack of support from state agencies and external institutions, their collective and individual investments are unable to address the underlying factors that create and perpetuate risk traps. In the periphery, inhabitants' uncertainty as to which investments have a positive effect is reflected in the large diversity of collective and individual interventions that households turn to in order to improve their living conditions. In Barrios Altos, the high tenure insecurity as well as the constant deterioration and lack of maintenance of the quintas open up a space for mixed and speculative land uses over residential use.

Further, the surveys in both areas indicate that the inhabitants can rarely bundle their capacities to invest collaboratively to reduce and prevent risks, and rather tackle immediate threats on an as-and-when basis. While it is difficult to find evidence of sustainable investments, the survey has shown that efforts to develop communal solutions are often not accompanied by maintenance investments. As a result, communal infrastructure was often found to be in worse condition and associated with higher risks and maintenance problems than that developed by individual households. However, individual and fragmented improvements such as those undertaken at the household level to secure access to water and electricity provision in Barrios Altos are often insufficient to prevent the risk of fires, floods and water-related diseases. Residents have no choice but to connect and maintain the quinta-level water and sewerage pipes and electricity themselves in order to gain access to these services at the household level inside the building. The quintas' infrastructure was historically designed to meet the needs of a single family. Hence, the 33 family units that now occupy them on average severely overstretch the capacity of the existing infrastructure, and the quality of connections depends on the locally available skills and material as well as maintenance efforts. This highlights the need for public policies and programmes to acknowledge the piecemeal local investments made individually and collectively, and to build on existing local capacities to support risk reduction and prevention interventions in the long term. 
The reproduction of urbanization in risk is not an inevitable process. Its roots can be tackled by acting on a number of key areas:

First, everyday risks are constructed in an incremental and invisible way. Various interventions in the built environment - both formal and informal - often create "risk traps" or vicious risk accumulation cycles that are exacerbated by climate uncertainty and result in disaster events. Thus, policies and programmes need to be accompanied by intensive local monitoring efforts, for example in the form of urban observatories or action-learning platforms, to make the incremental effects on people's quality of life visible. At the same time, it is key to acknowledge that those households caught in risk traps require strategic, vigorous and concerted support.

Second, levels of vulnerability and risk are highly heterogeneous, even amongst people living in the same area. Factors like gender, socioeconomic dependency ratio, level of income, location and history of the settlement explain households' susceptibility to risk traps, and influence how and why women and men are often forced to internalize or externalize the possible effects of hazardous phenomena, instead of being able to prevent their occurrence. Yet public investments often fail to prioritize the most vulnerable areas and social groups. Place-based policies and programmes are required to allow for adjustments to the context-specific characteristics of the beneficiaries, thus identifying who is vulnerable, what kind of risks they are vulnerable to, where, why, and what capacity they have to act.

Third, the evaluation of government policies shows that there are plans and programmes designed for DRM at the national, regional and local levels, along with an increasing budget and a proactive legal and procedural framework to shift the focus from DRM to disaster risk reduction and prevention. However, the large gap between budget allocation to local authorities and the specific investments realized at the local scale highlights the need to strengthen the capacities of local governments to utilize existing, albeit scarce, financial resources more efficiently and reach target groups in a more effective way. This involves raising the capacity of public agencies at different levels to assess local needs and trends and to evaluate the direct and indirect impacts of their investments on risk reduction and prevention in the short, medium and long term.

Fourth, policymakers in DRM need to articulate their investments in relation to other ongoing and gradually accumulating, albeit small, risk-reducing investments made by local dwellers. They also need to evaluate the actual impacts of risk-increasing interventions, such as roads that promote the occupation of hazardous areas, as well as the impacts of not investing in improvements that can reduce people's vulnerability to everyday risks. Local residents have an enormous capacity to manage and invest in building their lives in the city; however, this capacity is obstructed by the lack of recognition of their status as entitled citizens, whether they are tenants, posesionarios (recognised dwellers with semi-property rights) or outright unrecognised occupants of the land. In this context, policies that promote individualized interventions, such as land titles, simply skirt over the rights of women and men to be part of the city, and thus do not respond to the underlying structural causes of risk cycles. This calls for more parity of participation to genuinely articulate the knowledge, experiences and capacities of ordinary citizens and public agencies to benefit wider groups of women and men living in risk.

Finally, it is important to consider synergies in dealing with disaster risk reduction, climate change, and vulnerability to everyday risks and small-scale episodic disasters when conceptualizing and implementing processes for alternative development. The convergence of extensive risks associated with low-severity and high-frequency events and intensive risks associated with major hazards contributes to the reproduction of risk accumulation cycles. Without a long-term perspective on how, where and why urban risk traps operate, state responses are likely to continue focusing on large-scale and low-frequency disasters, missing the invisible processes that affect a sizeable percentage of impoverished women and men on a daily basis in Lima and elsewhere across the urban global South. 


\section{BIOGRAPHIES}

Adriana Allen is Professor at the Bartlett Development Planning Unit (DPU), University College London (UCL), where she leads the Research Cluster on Environmental Justice, Urbanisation and Resilience and is actively engaged in various initiatives promoting trans-local learning and enhanced research capacity, both within UCL and internationally. She has 30 years of international experience in over 20 countries in Asia, Africa, and Latin America. Her work focuses on investigating and promoting transformative links between socio-environmental change and justice and sustainability in urban and peri-urban contexts.

Address: e-mail: a.allen@ucl.ac.uk

Linda Zilbert Soto is an independent consultant associated with the Bureau for Crisis Prevention and Recovery of the United Nations Development Programme (Peru). She is a founding member of LA RED (Red de Estudios Sociales en Prevención de Desastres en América Latina) and has over 30 years of experience in the field of disaster risk mitigation, reduction and prevention. She has worked across the whole of Latin America.

Address: e-mail: lindazilbert@gmail.com

Julia Wesely holds an MSc in Ecosystems, Governance and Globalization from the Stockholm Resilience Centre and is currently a PhD student at the Bartlett Development Planning Unit, UCL, where her research focuses on the development of integrated risk management in the city of Manizales, Colombia. Through her studies and the cLIMA sin Riesgo project, she aims to explore the different roles and challenges of urban small-scale and everyday risks and how they inform the integration of disaster risk management and urban planning discourses.

Address: e-mail: julia.wesely.13@ucl.ac.uk

Teresa Belkow completed a Master's Degree in Environment and Sustainable Development at the Bartlett Development Planning Unit, UCL. Since 2012. Since 2015, she joined the cLIMA sin Riesgo team as a Research Assistant based in Lima and played a key role in coordinating on the ground the settlement and household participatory survey conducted in Barrios Altos and José Carlos Mariátegui. Her interests span the right to the city to participatory research methodologies.

Address: e-mail: teresa.belkow@gmail.com

Vladimir Ferro is a Peruvian economist who Works at the Ministry of Economy and Finance of Peru (MEF). He conducted a detailed desk study for cLIMA sin Riesgo examining all direct and indirect risk mitigation public investments programmed and executed in Metropolitan Lima between 2010 and 2015.

Address: e-mail: vferro@mef.gob.pe

Rita Lambert is a Teaching Fellow at The Bartlett Development Planning Unit, University College London, specialised in spatial analysis and participatory mapping. As a co-investigator in cLIMA sin Riesgo, she led the design and piloting of the georeferenced surveys undertaken in two two study areas.

Address: e-mail: rita.lambert@ucl.ac.uk

Ian Langdown is a Research Officer working for the ODI's Water Policy Programme. Ian holds an MSc in Environment and Sustainable Development (Distinction) from the University College London 
(UCL) and a first-class degree in Civil Engineering. He supported cLIMA sin Riesgo as a research assistant and worked in the development of ReMapRisk in collaboration with other team members.

Address: e-mail: i.langdown@odi.org.uk

Amaru Samanamú is a young economist and independent consultant specialised in the field of disaster risk management. He contributed to the analysis of risk mitigation investments by the state in the context of cLIMA sin Riesgo.

Address: e-mail: amaru_6@hotmail.com

\section{ACKNOWLEDGEMENTS}

We are grateful to the Climate and Development Knowledge Network (CDKN) for supporting the research project that informs this article (cLIMA sin Riesgo - Grants RSGL 1201 and 1201a). We extend our sincere gratitude to team members Ian Langdown, Rossana Poblet and Amaru Samanamú for their contributions in gathering and processing part of the information shared here, and to coinvestigators Rita Lambert (DPU), Liliana Miranda (Foro Ciudades para la Vida), Carlos Escalante Estrada (Instituto de Desarrollo Urbano - CENCA), Silvia de los Rios (Centro de Documentación, Investigación y Asesoría Poblacional - CIDAP) and Marco Kamiya (UN-Habitat) for their inputs throughout the project. Last but not least, we are grateful to all the institutional actors, local community organizations and neighbours of Barrios Altos and José Carlos Mariátegui in Lima, who have been part of this initiative.

\section{FUNDING}

This document is an output from a project commissioned through the Climate and Development Knowledge Network (CDKN). CDKN is a programme funded by the UK Department for International Development (DFID) and the Netherlands Directorate-General for International Cooperation (DGIS) for the benefit of developing countries. The views expressed and information contained herein are not necessarily those of or endorsed by DFID, DGIS or the entities managing the delivery of CDKN, which can accept no responsibility or liability for such views, completeness or accuracy of the information, or any reliance placed on them.

\section{REFERENCES}

Allen, A, T Belkow, S de los Rios, C Escalante Estrada, R Lambert, R Poblet and L Zilbert Zoto (2015), Urban Risk: In search of new perspectives, cLIMA sin Riesgo, Policy Brief No 1, accessed 24 February 2017 at http://www.climasinriesgo.net/wp-

content/uploads/2015/07/CSR_Policy_Doc_August-2015_ENG_WEB.pdf.

Allen, A, L Zilbert and J Wesely, in collaboration with T Belkow, V Ferro, I Langdown, R Poblet and A Samanamú (2016), Capacities and investments in managing urban risk, cLIMA sin Riesgo, Policy Brief No 3, accessed 24 February 2017 at http://www.climasinriesgo.net/wpcontent/uploads/2017/01/FINAL_WP4-PB3-eng_corrected.pdf.

Bull-Kamanga, L (2003), "From everyday hazards to disasters: the accumulation of risk in urban areas", Environment and Urbanization Vol 15, No 1, pages 193-204.

da Silva, J (2014), City Resilience Index, Arup, London, accessed 23 February 2017 at http://publications.arup.com/Publications/C/City_Resilience_Framework.aspx.

Dodman, D, B Donald, K Francis, J Hardoy, C Johnson and D Satterthwaite (2013), "Understanding the nature and scale of urban risk in low- and middle- income countries and its implications for 
humanitarian preparedness, planning and response", Human Settlements discussion paper, International Institute for Environment and Development, London.

Ferro, V (2016), Public Financing Disaster Risk Management (in Spanish), Internal report prepared for the cLIMA sin Riesgo project, Lima.

Hewitt, K (1983), Interpretations of Calamity, Allen \& Unwin, Boston, 170 pages.

Huggel, C, A Raissig, M Rohrer, G Romero, A Diaz and N Salzmann (2015), "How useful and reliable are disaster databases in the context of climate and global change? A comparative case study analysis in Peru", Natural Hazards and Earth System Sciences Vol 15, No 3, pages 475-485.

IFRC (2011), No time for doubt: Tackling urban risk - A glance at urban interventions by Red Cross Societies in Latin America and the Caribbean, International Federation of Red Cross and Red Crescent Societies, Geneva, 104 pages.

IFRC (2016), 2016 World Disasters Report - Resilience: saving lives today and investing for tomorrow, International Federation of Red Cross and Red Crescent Societies, Geneva, 278 pages.

INEI (2013), Mapa de Pobreza Provincial y Distrital 2013, Instituto Nacional de Estadística e Informática, accessed 23 February 2017 at http://www.inei.gob.pe/media/MenuRecursivo/publicaciones_digitales/Est/Lib1261/index.html.

INEI (2015), 9 million 752 thousand Limeños celebrate 480 years of the founding of the city of Lima, Instituto Nacional de Estatistica e Informática press release, 17 January, accessed 23 February 2017 at http://www.inei.gob.pe/prensa/noticias/9-millones-752-mil-limenos-celebran-480-anos-de-fundacionde-la-ciudad-de-lima-8173/.

Jabeen, H, C Johnson and A Allen (2010), "Built-in resilience: learning from grassroots coping strategies for climate variability", Environment and Urbanization Vol 22, No 2, pages 415-431.

Lambert, R and A Allen (2016), "Participatory Mapping to Disrupt Unjust Urban Trajectories in Lima", in P Imperatore (editor), Geospatial Technology - Environmental and Social Applications InTech, accessed 23 February 2017 at http://www.intechopen.com/books/geospatial-technologyenvironmental-and-social-applications/participatory-mapping-to-disrupt-unjust-urban-trajectories-inlima.

Lambert, R and R Poblet (2016), Mapping to reduce urban risk, Policy Brief No 2, January, cLIMA sin Riesgo, accessed 23 February 2017 at http://www.climasinriesgo.net.

La Red (2013), DesInventar: Inventory system of the effects of disasters, Version 10.01.005, accessed 4 August 2016 at https://online.desinventar.org/.

Lavell, A (2012), "Reflections: Advancing development-based interpretations and interventions in disaster risk: Some conceptual and contextual stumbling blocks", Environmental Hazards Vol 11, No 3, pages 242-246.

Marulanda, M C, O D Cardona and A H Barbat (2010), "Revealing the socioeconomic impact of small disasters in Colombia using the DesInventar database", Disasters Vol 34, No 2, pages 552-570.

Mechler, R (2016), "Reviewing estimates of the economic efficiency of disaster risk management: opportunities and limitations of using risk-based cost-benefit analysis", Natural Hazards Vol 81, No 3, pages 2121-2147. 
Miles, S B, R A Green and W Svekla (2012), "Disaster risk reduction capacity assessment for precarious settlements in Guatemala City”, Disasters Vol 36, No 3, pages 365-381.

Miranda Sara, L and I Baud (2014), "Knowledge-building in adaptation management: concertación processes in transforming Lima water and climate change governance", Environment and Urbanization Vol 26, No 2, pages 505-524.

Mitchell, J K (1998), "Hazards in changing cities”, Applied Geography Vol 18, No 1, pages 1-6.

Quispe, Romero, J and T Arias Ävila (2015), Presentation of preliminary results, Instituto de Desarrollo Urbano - CENCA, Lima.

Satterthwaite, D, D Dodman and M Pelling (2016), Thematic Note - Cross-Cutting Theme: Extensive Risk, Urban Africa: Risk Knowledge, London.

Stern, M and M Echavarria (2013), "Investments in Watershed Services for the Rimac Watershed, Department of Lima, Peru", Forest Trends, 10 pages.

UNISDR (2011), "Chapter 2: Revealing risk", in Global Assessment Report, accessed 23 February 2017 at http://www.preventionweb.net/english/hyogo/gar/2011/en/what/index.html.

UNISDR (2015), The Pocket GAR 2015 - Making Development Sustainable: The Future of Disaster Risk Management, United Nations Office for Disaster Risk Reduction, Geneva, accessed 23 February 2017 at http://www.preventionweb.net/english/hyogo/gar/2015/en/gar-pdf/GAR15_Pocket_EN.pdf.

Wisner, B, P Blaikie, T Cannon and I Davis (2004), At Risk: natural hazards, people's vulnerability and disasters, Second edition, Routledge, New York, 134 pages.

World Bank (2016), Peru: A comprehensive strategy for financial protection against natural disasters, Washington, DC.

Zilbert Soto, L (2008), “Los desastres: ¿problemas no resueltos del desarrollo?”, in Territorio y Naturaleza: Desarrollo en Armonía, Perú hoy series, Vol 14.

Vásquez Huamán, E (2012), “The Peru which is invisible to the State: pending social inclusion in July 2012", Discussion paper, Centre for Research of the Universidad Pácifico, accessed 23 February 2017 at http://srvnetappseg.up.edu.pe/siswebciup/Files/DD1204\%20-\%20Vasquez.pdf.

\footnotetext{
${ }^{1}$ Hewitt, K (1983), Interpretations of Calamity, Allen \& Unwin, Boston, 170 pages; also Mitchell, J K (1998), "Hazards in changing cities", Applied Geography Vol 18, No 1, pages 1-6.

${ }^{2}$ IFRC (2011), No time for doubt: Tackling urban risk - A glance at urban interventions by Red Cross Societies in Latin America and the Caribbean, International Federation of Red Cross and Red Crescent Societies, Geneva, 104 pages; also Miles, S B, R A Green and W Svekla (2012), "Disaster risk reduction capacity assessment for precarious settlements in Guatemala City", Disasters Vol 36, No 3, pages 365-381; and Wisner, B, P Blaikie, T Cannon and I Davis (2004), At Risk: natural hazards, people's vulnerability and disasters, Second edition, Routledge, New York, 134 pages.

${ }^{3}$ da Silva, J (2014), City Resilience Index, Arup, London, accessed 23 February 2017 at http://publications.arup.com/Publications/C/City_Resilience_Framework.aspx; also Dodman, D, B Donald, K Francis, J Hardoy, C Johnson and D Satterthwaite (2013), "Understanding the nature and scale of urban risk in low- and middle- income countries and its implications for humanitarian preparedness, planning and response", Human Settlements discussion paper, International Institute for
} 
Environment and Development, London; and Jabeen, H, C Johnson and A Allen (2010), "Built-in resilience: learning from grassroots coping strategies for climate variability", Environment and Urbanization Vol 22, No 2, pages 415-431.

${ }^{4}$ Lavell, A (2012), "Reflections: Advancing development-based interpretations and interventions in disaster risk: Some conceptual and contextual stumbling blocks", Environmental Hazards Vol 11, No 3, pages 242-246; also Satterthwaite, D, D Dodman and M Pelling (2016), Thematic Note - CrossCutting Theme: Extensive Risk, Urban Africa: Risk Knowledge, London; and Zilbert Soto, L (2008), "Los desastres: ¿problemas no resueltos del desarrollo?", in Territorio y Naturaleza: Desarrollo en Armonía, Perú hoy series, Vol 14.

${ }^{5}$ IFRC (2016), 2016 World Disasters Report - Resilience: saving lives today and investing for tomorrow, International Federation of Red Cross and Red Crescent Societies, Geneva, 278 pages.

${ }^{6}$ Marulanda, M C, O D Cardona and A H Barbat (2010), "Revealing the socioeconomic impact of small disasters in Colombia using the DesInventar database", Disasters Vol 34, No 2, pages 552-570; also UNISDR (2011), "Chapter 2: Revealing risk", in Global Assessment Report, accessed 23 February 2017 at http://www.preventionweb.net/english/hyogo/gar/2011/en/what/index.html.

${ }^{7}$ See reference 4 (Satterthwaite et al, 2016); also Bull-Kamanga, L (2003), "From everyday hazards to disasters: the accumulation of risk in urban areas", Environment and Urbanization Vol 15, No 1, pages 193-204.

${ }^{8}$ Mechler, R (2016), "Reviewing estimates of the economic efficiency of disaster risk management: opportunities and limitations of using risk-based cost-benefit analysis", Natural Hazards Vol 81, No 3, pages 2121-2147, page 2128.

${ }^{9}$ See http://www.climasinriesgo.net for the bilingual project website.

${ }^{10}$ By Metropolitan Lima, we refer to the administrative jurisdiction of Lima and Callao

${ }^{11}$ Allen, A, T Belkow, S de los Rios, C Escalante Estrada, R Lambert, R Poblet and L Zilbert Zoto (2015), Urban Risk: In search of new perspectives, cLIMA sin Riesgo, Policy Brief No 1, page 4, accessed 24 February 2017 at http://www.climasinriesgo.net/wpcontent/uploads/2015/07/CSR_Policy_Doc_August-2015_ENG_WEB.pdf.

${ }^{12}$ UNISDR (2015), The Pocket GAR 2015 - Making Development Sustainable: The Future of Disaster Risk Management, United Nations Office for Disaster Risk Reduction, Geneva, accessed 23 February 2017 at http://www.preventionweb.net/english/hyogo/gar/2015/en/gar-pdf/GAR15_Pocket_EN.pdf.

${ }^{13}$ Allen, A, L Zilbert and J Wesely, in collaboration with T Belkow, V Ferro, I Langdown, R Poblet and A Samanamú (2016), Capacities and investments in managing urban risk, cLIMA sin Riesgo, Policy Brief No 3, accessed 24 February 2017 at http://www.climasinriesgo.net/wpcontent/uploads/2017/01/FINAL_WP4-PB3-eng_corrected.pdf.

${ }^{14}$ Huggel, C, A Raissig, M Rohrer, G Romero, A Diaz and N Salzmann (2015), "How useful and reliable are disaster databases in the context of climate and global change? A comparative case study analysis in Peru", Natural Hazards and Earth System Sciences Vol 15, No 3, pages 475-485.

${ }^{15}$ INEI (2013), Mapa de Pobreza Provincial y Distrital 2013, Instituto Nacional de Estadística e Informática, accessed 23 February 2017 at http://www.inei.gob.pe/media/MenuRecursivo/publicaciones_digitales/Est/Lib1261/index.html.

${ }^{16}$ La Red (2013), DesInventar: Inventory system of the effects of disasters, Version 10.01.005, accessed 4 August 2016 at https://online.desinventar.org/. 
${ }^{17}$ World Bank (2016), Peru: A comprehensive strategy for financial protection against natural disasters, Washington, DC.

${ }^{18}$ See reference 15 .

${ }^{19}$ INEI (2015), 9 million 752 thousand Limeños celebrate 480 years of the founding of the city of Lima, Instituto Nacional de Estatistica e Informática press release, 17 January, accessed 23 February 2017 at http://www.inei.gob.pe/prensa/noticias/9-millones-752-mil-limenos-celebran-480-anos-defundacion-de-la-ciudad-de-lima-8173/.

${ }^{20}$ Vásquez Huamán, E (2012), "The Peru which is invisible to the State: pending social inclusion in July 2012", Discussion paper, Centre for Research of the Universidad Pácifico, accessed 23 February 2017 at http://srvnetappseg.up.edu.pe/siswebciup/Files/DD1204\%20-\%20Vasquez.pdf.

${ }^{21}$ Stern, M and M Echavarria (2013), "Investments in Watershed Services for the Rimac Watershed, Department of Lima, Peru”, Forest Trends, 10 pages.

${ }^{22}$ See reference 19.

${ }^{23}$ Miranda Sara, L and I Baud (2014), "Knowledge-building in adaptation management: concertación processes in transforming Lima water and climate change governance", Environment and Urbanization Vol 26, No 2, pages 505-524.

${ }^{24}$ See reference 19 .

${ }^{25}$ Quispe, Romero, J and T Arias Ävila (2015), Presentation of preliminary results, Instituto de Desarrollo Urbano - CENCA, Lima.

${ }^{26}$ See reference 15 .

${ }^{27}$ The paper applies conversion rates from Peruvian soles (PEN) to US\$ for the date of 1 January according to the year when the programme starts. Hence, for a programme from 2011 to 2015, the conversion rate is from 1 January 2011.

${ }^{28}$ Ferro, V (2016), Public Financing Disaster Risk Management (in Spanish), Internal report prepared for the cLIMA sin Riesgo project, Lima.

${ }^{29}$ For a more detailed explanation of the methodological approach adopted, see Lambert, $\mathrm{R}$ and A Allen (2016), "Participatory Mapping to Disrupt Unjust Urban Trajectories in Lima", in P Imperatore (editor), Geospatial Technology - Environmental and Social Applications InTech, accessed 23 February 2017 at http://www.intechopen.com/books/geospatial-technology-environmental-and-socialapplications/participatory-mapping-to-disrupt-unjust-urban-trajectories-in-lima; also Lambert, $\mathrm{R}$ and $\mathrm{R}$ Poblet (2016), Mapping to reduce urban risk, Policy Brief No 2, January, cLIMA sin Riesgo, accessed 23 February 2017 at http://www.climasinriesgo.net.

${ }^{30}$ See reference 24 . 